\title{
How much bloating in the irritable bowel syndrome?
}

\author{
LUCIAN LIVIU POP ${ }^{1}$, IULIA ANTONIA MUREŞAN ${ }^{1}$, DAN LUCIAN DUMITRAŞCU ${ }^{1}$ \\ 1 “Iuliu Hațieganu” University of Medicine and Pharmacy, Medical Clinic II
}

\begin{abstract}
The irritable bowel syndrome (IBS) is the most common chronic gastrointestinal disorder referred to gastroenterologists. One of the most common manifestations of IBS is bloating. Abdominal bloating is defined as subjective sensation of abdominal distension associated with girth increment. Therefore, it is described in the Rome IV criteria as bloating/abdominal distension. Bloating symptoms are reported by $10-30 \%$ of the general population and it was rated as the most bothersome symptom by $60 \%$ of IBS patients; the lack of specificity of this complaint prevented bloating to be included between the diagnostic criteria for IBS. Indeed, bloating may be reported also in healthy people or in other functional conditions.

This paper looks to the evolutions of the concepts on bloating according to the Rome working groups from the beginning until now and it represents a comprehensive review on the prevalence and pathogenesis of bloating.
\end{abstract}

Keywords: Bloating, functional gastrointestinal disorders, irritable bowel syndrome, Rome criteria.

\section{INTRODUCTION}

The concept of irritable bowel syndrome (IBS) suffered minor changes in definition and diagnosis in the last decades; however, the individualization of this entity relied on a more or less group of symptoms used. Being the most common chronic gastrointestinal disorder referred to gastroenterologists [1] it is commonly characterized by abdominal pain and/or/without abdominal discomfort, associated with altered bowel movement consistency and frequency expressed by constipation or diarrhea [2]. It is a functional disorder, not an organic disease often associated with psychological disorders [3].

\section{A HISTORICAL APPROACH}

The Rome criteria have evolved from the work of a group invited by Aldo Torsolli during the International Congress of Gastroenterology and published in 1989 (The Rome Guidelines for IBS) [4] through the Rome Classification System for FGIDs (1990) [5]. In the years that followed, the Rome experts group have elaborated a total of four editions of the Rome Classification System for FGIDs in order to define and update with the scientific progress, the functional disorders, including IBS and bloating. These Rome group meetings have been helpful in popularizing the term IBS and providing concrete symptom criteria [6]. The first standardized definition of IBS accompanied by diagnostic criteria evolved from the Rome I working group. According to this, IBS is defined as in Table 1 [7].

Some years later, the definition was mildly altered, and in Rome II criteria for IBS is presented in Table 2 [8].

More recently, according to the Rome III diagnostic consensus, IBS was defined as recurrent abdominal pain or discomfort for at least three days per month in the last three months and with two or more of the following: improvement with defecation, onset associated with a change in frequency of stool or onset associated with a change in form of stool [3]. Rome III criteria for IBS are presented in Table 3. There are four main subtypes of IBS: IBS with constipation (IBS-C), IBS with diarrhea (IBS-D), mixed (IBS-M) and unclassified (IBSU). IBSC, is characterized by hard or lumpy stool with $\geq 25 \%$ of bowel movements and loose or watery stool with $<$ $25 \%$ of bowel movements. Loose or watery stool with $\geq 25 \%$ of bowel movements and hard or lumpy stool with $<25 \%$ of bowel movements is indicative of IBS-D. IBS-M is characterized by lumpy stool with $>25 \%$ of bowel movements and loose or watery stool with $\geq 25 \%$ of bowel movements [9].

The latest version of the Rome working groups, Rome IV, has introduced changes in the diagnostic criteria of IBS based on the available evidences and on the target population $[10,11]$. From the Rome IV criteria, the term discomfort was eliminated based on a survey, because discomfort is a nonspecific term and should lead to confusions. The term "discomfort" has different meanings in 
different languages and is an ambiguous term for patients [10].

According to the Rome IV criteria only abdominal pain and not abdominal discomfort is now necessary to define IBS. Patients need to present pain minimum one day per week, in the last three months. This was proved by a study that showed a frequency of less than one day per week for abdominal pain present in healthy subjects $[11,12]$. Rome IV criteria for IBS are presented in Table 4.

Table 1

Definition of irritable bowel syndrome according to the Rome I consensus report from Drossman et al. 1994 [7]

Continuous or recurrent symptoms for at least 3 months of:

1. Abdominal pain or discomfort relieved with defecation, or associated with a change in frequency or consistency of stool

2. An irregular varying pattern of defecation at least $25 \%$ of the time (three or more of):

a. altered stool frequency

b. altered stool form (hard or loose/watery stool)

c. altered stool passage (straining or urgency, feeling of incomplete evacuation)

d.passage of mucus

e. bloating or feeling of abdominal distension

Table 2

ROME II Diagnostic criteria for Irritable Bowel Syndrome [8]

At least 12 weeks, which need not be consecutive, in the preceding 12 months of abdominal discomfort or pain that has two out of three features

1. Relieved with defecation; and/or

2. Onset associated with a change in frequency of stool; and/or

3. Onset associated with a change in form (appearance) of stool.

Symptoms that cumulatively support the diagnosis of irritable bowel syndrome

- Abdominal stool frequency (for research purpose "abnormal" may be defined as greater than 3 bowel movements per day and less than 3 bowel movements per week);

- Abnormal stool form (lumpy/hard or loose/watery stool);

- Abnormal stool passage (straining, urgency, or feeling of incomplete evacuation);

- Passage of mucus;

- Bloating or feeling of abdominal distension.

Table 3

ROME III Diagnostic criteria* for Irritable Bowel Syndrome [3]

Recurrent abdominal pain or discomfort** at least 3 days/month in the last 3 months associated with two or more of the following:

1. Improvement with defecation

2. Onset associated with a change in frequency of stool

3. Onset associated with a change in form (appearance) of stool

* Criterion fulfilled for the last 3 months with symptom onset at least 6 months prior to diagnosis

** "Discomfort" means an uncomfortable sensation not described as pain.

In pathophysiology research and clinical trials, a pain/discomfort frequency of at least 2 days a week during screening evaluation is recommended for subject eligibility.

Table 4

ROME IV Diagnostic criteria for Irritable Bowel Syndrome [12]

Must fulfill criteria 1, 2 and 3 for the last 3 months:

1. Recurrent abdominal pain (at least once a week)

2. Pain is associated with two or more of the following criteria:

a. Related to defecation (at least $30 \%$ of occasions)

b. Associated with a change in form (appearance) of stool (at least $30 \%$ of occasions)

c. Associated with a change in frequency of stool (at least $30 \%$ of occasions)

3. Symptoms onset at least 6 months prior to diagnosis

Table 5

Diagnostic criteria* for functional bloating [3]

They must include both of the following:

1. Recurrent feeling of bloating or visible distension at least 3 days/month in the last 3 months

2. Insufficient criteria for a diagnosis of functional dyspepsia, irritable bowel syndrome, or other functional GI disorder

* Criteria fulfilled for the last 3 months with symptom onset at least 6 months prior to diagnosis 
Rome Foundation managed a study in the general population from the USA, with the aim to observe the frequency of normal bowel habits [13]. The purpose was to identify the prevalence of normality in order to statistically derive abdominal frequencies consistent with disorders of gut-brain interaction. Based on this study the Rome Foundation committees recommend the 90th percentile symptom frequency on both sexes as the threshold to explain normality [11]. In the general population, discomfort or abdominal pain was reported for less than 3 days per month, and for $6.7 \%$ of the population at least once a week both symptoms. Hence, according to the Rome IV criteria, the frequency limit for pain in IBS was set at a minimum of once a week [11, 14].

In addition, pain or discomfort had to improve with defecation according to Rome III criteria. Although, in many patients pain remains without changes or even increases with defecation [15]. Also, in Rome III, pain or discomfort symptom had to be associated with change in frequency of stools or change of form of stool [16]. Since not in all IBS patients abdominal pain is associated with stool changes, the term "onset" was excluded from Rome IV criteria [14].

As a result of changes from Rome III to Rome IV in IBS criteria, the prevalence of IBS decreases by half from $11.1 \%$ to $6.1 \%$ in the USA, from $11.7 \%$ to $5.8 \%$ in Canada and from $10.6 \%$ to $5.5 \%$ in the UK, after applying the Rome IV IBS criteria in English speaking populations for the first time. These changes can be related to the elimination of discomfort from the criteria [17].

\section{BLOATING IN IBS}

Abdominal bloating is defined as subjective sensation of abdominal distension associated with a real girth increment [18]. The pathogenesis of bloating includes several factors: a subjective sensation of abdominal bloating, objective abdominal distension, volume of intra- abdominal contents and muscular activity of the abdominal wall. These factors may act independently or associated [19]. The investtigations of the transit of gas showed that in bloating the gut reflex controlling its content is impaired. The segmental contractions of the bowel may cause the sensation of distension, mainly in cases with poor visceral sensitivity [20].

If in the bowels the volume of gas is increased, as it occurs after the consumption of certain legumes, due to the biochemical processing of colon bacteria, some individuals may complain of bloating and/or distension. There is no direct correlation between the clinical intensity of the symptom and the amount of abdominal gas. The muscular tone of the abdomen is also involved in bloating perception [21].

Bloating is frequently encountered in IBS, however in the four editions of the Rome working committees, there was no mention to include bloating in the diagnostic criteria of IBS. In the current gold standard classification of functional gastrointestinal disorders, abdominal bloating and distention are considered as secondary descriptors $[22,23]$. Patients with bloating have to be well questioned and investigated to rule out functional dyspepsia. Those subjects, who do not meet the criteria for these categories, may be labeled as having functional bloating [19].

According to ROME III working group, functional bloating is defined as a recurrent sensation of abdominal distension that may or may not be associated with measurable distension but it is not part of another functional bowel or gastroduodenal disorder [3].

Functional bloating is diagnosed when abdominal bloating as a subjective symptom and/or distension as a visible increase in abdominal girth predominate over other symptoms. Rome IV recognizes that patients may also report symptoms of mild abdominal pain and/or minor bowel movement abnormalities [13]. Rome IV diagnostic criteria for functional abdominal bloating/distension are presented in Table 6 [12].

Table 6

Functional abdominal bloating/distension [12]

Diagnostic criteria* must include both of the following:

1. Recurrent bloating and/or distension occurring on average at least 1 day/week; abdominal bloating and/or distension predominates over other symptoms**

2. There are insufficient criteria for a diagnosis of irritable bowel syndrome, functional constipation, functional diarrhea, or postprandial distress syndrome

* Criteria fulfilled for the last 3 months with symptom onset at least 6 months prior to diagnosis

** Mild pain related to bloating may be present as well as minor bowel movement abnormalities 
The correct recognition of bloating is difficult in many languages, like Latin languages, where bloating may be confused with epigastric postprandial distention, typical in functional dyspepsia [24]. Therefore, it is important to make sure that the patient is complaining of true abdominal bloating (distension) and not on postprandial distress syndrome.

Abdominal bloating is a very common and embarrassing problem being reported by up to $30 \%$ of the general population [25-27]. It is a very subjective complaint among IBS patients, who describe it as a sensation of abdominal fullness with or without measurable increase in abdominal girth [21, 28-30].

In one study, bloating was the most bothersome symptom for $60 \%$ of IBS patients. In another study, almost all (90\%) IBS patients reported bloating [25]. In a large study led by Safaee et al., bloating was rated as the most bothersome symptom by more than $60 \%$ of the patients participated in the study. In the same study, bloating symptoms were reported $58.3 \%$ by IBS-C, $65.7 \%$ by IBS-D and $81.3 \%$ by IBS-I [31], which is different from previous reports that noted high presence of bloating in IBS-C patients [25, 32, 33].

Similar data come from the Far East: thus, in a Japanese online survey, Kanazawa et al. reported that up to $30 \%$ of healthy subjects and almost all IBS patients may be affected by bloating [34].

There are differences in bloating prevalence according to IBS type. In the majority of studies, the prevalence is higher in constipation-predominant IBS patients compared with diarrheapredominant IBS patients, while some investigators found no relation of bloating to any of IBS subtype $[35,36]$. A strong correlation between the severity of abdominal bloating and the degree of abdominal distension only in patients with constipation predominant IBS suggest that the pathophysiology may be different between subtypes of IBS [34, 37]. Using plethysmography it has been demonstrated that most patients with abdominal distension also report abdominal bloating and that patients with bloating alone have lower sensory thresholds in the rectum compared to healthy subjects, since those with abdominal bloating and distension have normal or higher sensory thresholds [38]. But then, the increase in abdominal girth has been reported directly correlated with orocecal and colonic transit times, and inversely correlated with stool consistency [39]. Accordingly, abdominal bloating alone is rather the consequence of perturbed visceral sensitivity [34].

Using colonic gas infusion, a study demonstrated that colonic gas load is associated with significant increase of activity of the abdominal muscles assessed by electromyography $[40,41]$. This contraction is associated with diaphragmatic relaxation, contributing to the unpleasant symptoms of bloating $[42,44]$. In functional patients, the abdominal accommodation reflex is abnormal $[43,44]$. Thus, beside the transit of gas in the bowel, wall musculature and diaphragm contribute to the occurrence of distension $[18,42]$. This abdomino-phrenic incoordination is associated with abdominal distension more frequently in women than in males and more frequently during menses [45].

Bloating in IBS may be worsened by stress [46] and relieved by relaxation [47].

IBS patients often relate their symptoms to the intake of certain foods. Bloating occurs or is exacerbated postprandial in approximately two-thirds of patients $[48,49]$. The presence of the symptom following meals intake is explained by increased visceral perception, increased gut contractions and impaired propulsive movement in response to the nutrition [34].

Abdominal bloating is associated with decreased QoL and may cause a higher healthcare utilization and use of medications [46].

\section{CONCLUSIONS}

Abdominal bloating/distension is an important and frustrating clinical condition. It can occur in some cases as a functional gastrointestinal disorder, but frequently also as an associated symptom to IBS. It should be differentiated from the functional dyspepsia of the type postprandial distress syndrome. Abdominal bloating has a high prevalence and considerable impact on the daily lives of subjects diagnosed with IBS. However, it is not specific enough to warrant its inclusion in the Rome diagnostic criteria for IBS.

Sindromul intestinului iritabil (SII) este cea mai comună tulburare cronică gastrointestinală adresată gastroenterologilor. Balonarea este una din cele mai comune manifestări ale SII. Balonarea este definită ca senzația subiectivă de distensie abdominală asociată cu creşterea circumferinței abdominale. Prin 
urmare ea este descrisă comform criteriilor Roma IV ca balonare/distensie abdominală. Deşi simptomele de balonare sunt raportate de $10-30 \%$ din populația generală şi a fost evaluat drept cel mai deranjant simptom de către $60 \%$ din pacienții suferind de SII, totuşi nu este inclus în criteriile de diagnostic Roma pentru SII. Având în vedere faptul că balonarea este prezentă în cazul pacienților suferinzi de orice tulburare funcțională intestinală şi chiar la subiecții sănătoşi, înseamnă că într-adevăr aceasta nu trebuie considerată un criteriu de diagnostic pentru SII. Acest articol este o revizuire asupra evoluției conceptelor cu referire la balonare comform grupului de lucru Roma de la originile acestuia până în prezent şi o revizuire cuprinzătoare asupra prevalenței şi patogenezei acestei manifestări.

Correspondence to: Prof. Dan Lucian Dumitraşcu, "Iuliu Hațieganu” University of Medicine and Pharmacy,

Medical Clinic II, Clinicilor 2-4, Cluj-Napoca, Romania

E-mail: ddumitrascu@umfcluj.ro

\section{REFERENCES}

1. AKBAR A, WALTERS JR, GHOSH S. Review article: visceral hypersensitivity in irritable bowel syndrome: molecular mechanisms and therapeutic agents. Aliment Pharmacol Ther. 2009; 30:423-435.

2. DROSSMAN DA, DUMITRASCU DL. Rome III: New Standard for Functional Gastrointestinal Disorders. J Gastrointestin Liver Dis. 2006 Sep; 15(3):237-41.

3. APPENDIX A: Rome III diagnostic criteria for functional gastrointestinal disorders. In: Drossman D, editor. Rome III: The functional gastrointestinal disorders. Raleigh (NC): Rome Foundation. 2006:885-97.

4. THOMPSON WG, DOTEVALL G, DROSSMAN DA, HEATON KW, KRUIS W. Irritable bowel syndrome: guidelines for the diagnosis. Gastroenterol Int. 1989; 2:92-5.

5. DROSSMAN DA, THOMPSON WG, TALLEY NJ, FUNCH-JEASEN P, JANSSENS J. Identification of subgroups of functional bowel disorders. Gastroenterol Int. 1990; 3:159-172.

6. MALAGELADA JR, MALAGELADA C. Mechanism-oriented therapy of irritable bowel syndrome. Adv Ther. 2016 Jun; 33(6):877-893.

7. DROSSMAN DA, RICHTER JE, TALLEY NJ, THOMPSON WG, CORAZZIARI E, WHITEHEAD WE. The functional gastrointestinal disorders: diagnosis, pathophysiology and treatment. McLean, VA: Degnon Associates. 1994.

8. DROSSMAN DA, CORAZZIARI E, TALLEY NJ, et al. Rome II. The functional gastrointestinal disorders. McLean, VA: Degnon. 2000.

9. OTTAWA ON. Trimebutine Maleate and Pinaverium Bromide for irritable bowel syndrome: A review of the clinical effectiveness, safety and guidelines. Canadian Agency for Drugs and Technologies in Health. 2015 Nov.

10. SPIEGEL BM, BOLUS R, AGARWAL N, et al. Measuring symptoms in the irritable bowel syndrome: development of a framework for clinical trials. Aliment Pharmacol Ther. 2010; 32:1275-1291.

11. PALSSON OS, WHITEHEAD WE, VAN TILBURG MA, et al. Development and validation of the Rome IV diagnostic questionnaire for adults. Gastroenterology. 2016; 150:1481-1491.

12. WHITEHEAD EE, PALSSON OS, M.A.L. VT, SPERBER A, B. S, TACK J, WALKER LS, Y.Y. Development and validation of the Rome IV diagnostic questionnaires. In: Drossman DA, Chang LC, W Kellow J, Tack J, Whitehead WE, The Rome IV Committees, eds. Rome IV diagnostic questionnaires and tables for investigators and clinicians. Raleigh, NC: The Rome Foundation. 2016:43-92.

13. SCHMLSON MJ, DROSSMAN DA. What is New in Rome IV. J Neurogastroenterol Motil. 2017 Apr 30; 23(2):151-163.

14. MEARIN F, LACY BE, CHANG L, et al. Bowel Disorders. Gastroenterology. 2016:150; 1393-1407, e5.

15. HELLSTROM PM, SAITO YA, BYTZER P, TACK J, MUELLER-LISSNER S, CHANG L. Characteristics of acute pain attacks in patients with irritable bowel syndrome meeting Rome III criteria. Am J Gastroenterol. 2011; 106:1299-1307.

16. LONGSTRETH GF, THOMPSON WG, CHEY WD, HOUGHTON LA, MEARIN F, SPILLER RC. Functional bowel disorders. Gastroenterology. 2006; 130:1480-1491.

17. PALSON O, VAN TILBURG M, SIMREN M, SPERBER AD, WHITHEAD W. Mo1642 population prevalence of Rome IV and Rome III irritable bowel syndrome (IBS) in the United States (US), Canada and the United Kingdom (UK). Gastroenterology. 2016; 150:S739-S740.

18. VILLORIA A, AZPIROZ F, BURRI E. Abdomino-phrenic dyssynergia in patients with abdominal bloating and distension. Am J Gastroenterol. 2011; 106:815-9.

19. AZPIROZ F, MALAGELADA JR. Abdominal bloating. Gastroenterology. 2005; 129:1060-1078.

20. PASSOS MC, SERRA J, AZPIROZ F, TREMOLATERRA F, MALAGELADA JR. Impaired reflex control of intestinal gas transit in patients with abdominal bloating. Gut. 2005; 54:344-348.

21. SERRA J, SALVIOLI B, AZPIROZ F, MALAGELADA JR. Lipid-induced intestinal gas retention in irritable bowel syndrome. Gastroenterology. 2002; 123:700-706. 
22. TALLEY N, STANGHELLINI V, HEADING RC, KOCH KL, MALAGELADA JR, TYTGAT GN. Functional gastroduodenal disorders. In Drossman DA, Corazziari E, Talley N, Thompson WG, Whitehead WE, eds. The Functional Gastrointestinal Disorders. Rome II. $2^{\text {nd }}$ ed. McLean, VA. Degnono Associates. 2000:299-350.

23. THOMPSON WG, LONGSTRETH G, DROSSMAN DA, HEATON K, IRVINE EJ, MULLER-LISSNER SC. Functional bowel disorders in functional abdominal pain. In: Drossman DA, Corazziari E, Talley NJ, Thompson WG, Whitehead WE, eds. The Functional Gastrointestinal Disorders. $2^{\text {nd }}$ ed. McLean, VA. Degnono Associates. 2000:351-432.

24. MEARIN F, LACY BE, CHANG L, CHEY WD, LEMBO AJ, SIMRÉN M, SPILLER R. BOWEL DISORDERS. IN: DROSSMAN DA, CHANG LC, W KELLOW J, TACK J, WHITEHEAD WE. The Rome IV Committees, eds. Rome IV functional gastrointestinal disorders - disorders of gut-brain interaction. Volume II. Raleigh, NC. The Rome Foundation. 2016:967-1057.

25. CHANG L, LEE OY, NALIBOFF B, SCHMULSON M, MAYER EA. Sensation of bloating and visible abdominal distension in patients with irritable bowel syndrome. Am J Gastroenterol. 2001; 96:3341-47.

26. TALLEY NJ, HOLTMANN G, AGREUS L, JONES M. Gastrointestinal symptoms and subjects cluster into distinct upper and lower groupings in the community: a four nations study. Am J Gastroenterol. 2000; 95:1439-47.

27. SANDLER RS, STEWART WF, LIBERMAN JN, RICCI JA, ZORICH NL. Abdominal pain, bloating, and diarrhea in the United States: prevalence and impact. Dig Dis Sci. 2000; 45:1166-71.

28. SAHA L. Irritable bowel syndrome: pathogenesis, diagnosis, treatment, and evidence-based medicine. World J Gastroenterol. 2014 Jun 14; 20(22):6759-73.

29. HOUGHTON LA, WHORWELL PJ. Towards a better understanding of abdominal bloating and distension in functional gastrointestinal disorders. Neurogastroenterol Motil. 2005; 17:500-11.

30. LASSER RB, BOND JH, LEVITT MD. The role of intestinal gas in functional abdominal pain. N Engl J Med. 1975; 293:524-526.

31. SAFAEE A, MOGHIMI-DEHKORDI B, POURHOSEINGHOLI F. Bloating in irritable bowel syndrome. Clin Gastroenterol Hepatol Bed Bench. 2011; 4(2):86-90.

32. RINGEL Y, WILLIAMS RE, KALILANI L, COOK SF. Prevalence, characteristics, and impact of bloating symptoms in patients with irritable bowel syndrome. Clin Gastroenterol Hepatol. 2009; 7:68-72.

33. SCHMULSON M, LEE OY, CHANG L, NALIBOFF B, MAYER EA. Symptom differences in moderate to severe IBS patients based on predominant bowel habit. Am J Gastroenterol. 1999; 94:2929-35.

34. KANAZAWA M, MIWA H, NAKAGAWA A, KOSAKO M, AKIHO H, FUKUDO S. Abdominal bloating is the most bothersome symptom in irritable bowel syndrome with constipation (IBS-C): a large population-based internet survey in Japan. Biopsychosoc Med. 2016 Jun 4; 10-19.

35. TALLEY NJ, DENNIS EH, SCHETTLER-DUNCAN VA, LACY BE, OLDEN KW, CROWELL MD. Overlapping upper and lower gastrointestinal symptoms in irritable bowel syndrome patients with constipation or diarrhea. Am J Gastroenterol. 2003; 98:2454-59.

36. RAGNARSSON G, BODEMAR G. Division of the irritable bowel syndrome into subgroups on the basis of daily recorded symptoms in two outpatients samples. Scand J Gastroenterol. 1999; 34:993-1000.

37. HOUGHTON LA, LEA R, AGRAWAL A, REILLY B, WHORWELL PJ. Relationship of abdominal bloating to distention in irritable bowel syndrome and effect of bowel habit. Gastroenterology. 2006; 131:1003-10.

38. AGRAWAL A, HOUGHTON LA, LEA R, MORRIS J, REILLY B, WHORWELL PJ. Bloating and distention in irritable bowel syndrome: the role of visceral sensation. Gastroenterology. 2008; 134:1882-9.

39. AGRAWAL A, HOUGHTON LA, REILLY B, MORRIS J, WHORWELL PJ. Bloating and distension in irritable bowel syndrome: the role of gastrointestinal transit. Am J Gastroenterol. 2009; 104:1998-2004.

40. LUO YM, MUSTFA N, LYALL RA et al. Diaphragm compound muscle action potential measured with magnetic stimulation and chest wall surface electrodes. Respir Physiol Neurobiol. 2002; 130:275-83.

41. POP LL, MURESAN IA, DUMITRASCU DL. Electromyographic recording of the abdominothoracic wall in the study of the abdominal accommodation. Archives of the Balkan Medical Union. 2015; 2:254-257.

42. VERIN E, STRAUS C, DEMOULE A et al. Validation of improved recording site to measure phrenic conduction from surface electrodes in humans. J Appl Physiol. 2002; 92:967-74.

43. TREMOLATERRA F, SERRA F, AZPIROZ F et al. Bloating and abdominal wall dystony. Gastroenterology. $2004 ; 126:$ A53.

44. VILLORIA A, AZPIROZ F, MALAGELADA JR. Abdomino-phrenic dyssynergia, abdominal bloating and distension. Neurogastroenterol Mot. 2006; 18:A229.

45. LEE OY, MAYER EA, SCHMULSON M, CHANG L, NALIBOFF B. Gender-related differences in IBS symptoms. Am J Gastroenterol. 2001; 96:2184-93.

46. TUTEJA AK, TALLEY NJ, JOOS SK, TOLMAN KG, HICKAM DH. Abdominal bloating in employed adults: prevalence, risk factors, and association with other bowel disorders. Am J Gastroenterol. 2008; 103:1241-8.

47. HASLER WL. Irritable bowel syndrome and bloating. Best pract Res. 2007; 21:689-707.

48. MONSBAKKEN KW, VANDVIK PO, FARUP PG. Perceived food intolerance in subjects with irritable bowel syndromeetiology, prevalence and consequences. Eur J Clin Nutr. 2006; 60:667-72.

49. SIMRÉN M, MANSSON A, LANGKILDE AM, SVEDLUND J, ABRAHAMSSON H, BENGTSSON U, BJORNSSON ES. Food-related gastrointestinal symptoms in the irritable bowel syndrome. Digestion. 2001; 63:108-15.

Received February 13, 2018 